\title{
A INTEGRAÇÃO FÍSICA SUL-AMERICANA NO PERÍODO RECENTE (2000-2020): SITUAÇÃO, CONTINUIDADE, INFLEXÃO E REVERSÃO
}

\author{
Thais Virga ${ }^{1}$ \\ Tomás Costa de Azevedo Marques²
}

\begin{abstract}
Diante do processo de globalização econômica e de decorrentes investimentos realizados na criação de eixos de conexão para atender à crescente comercialização de produtos e serviços e à circulação de pessoas, ficam evidentes, em tempo e espaço, enormes diferenças entre países desenvolvidos e subdesenvolvidos, acarretando a maior oferta e integração de malhas viárias em favor daqueles. A América do Sul, apesar de histórica e estruturalmente apresentar expressivos atrasos em termos infraestruturais, com conexões mais voltadas "para fora" que "para dentro", e haja vista o acúmulo de carências e desafios até a atualidade, nos últimos anos pareceu avançar no quesito integração física territorial, em planos e obras. Partindo da inter-relação entre tais aspectos, este artigo propõe debater sobre a questão dos transportes durante o período 2000-2020, com ênfase em políticas e investimentos efetuados e previstos, em linha com duas iniciativas de integração física regional: a Iniciativa para a Integração da Infraestrutura Regional Sul-Americana (IIRSA), de 2000, e o Conselho de Infraestrutura e Planejamento (Cosiplan), de 2009. Especificamente a partir de um diagnóstico recente da situação da infraestrutura sul-americana, a discussão avançará aos pontos de continuidade e inflexão entre tais agendas entre 2000 e 2016, com maior foco no Cosiplan. Então, com base em um cenário político-econômico complexificado na América do Sul, novas conjunturas e prospectivas sobre a integração física são apresentadas, indicando um movimento de considerável reversão da questão infraestrutural no subcontinente.
\end{abstract}

Palavras-chave: integração física; América do Sul; transportes; IIRSA; Cosiplan.

\section{SOUTH AMERICAN PHYSICAL INTEGRATION IN THE RECENT PERIOD (2000-2020): SITUATION, CONTINUITY, INFLECTION AND REVERSION}

In view of the process of economic globalization and the resulting investments made in the creation of connection axes to meet the growing commercialization of products and services and the circulation of people, huge differences between developed and underdeveloped countries are evident in time and space, resulting in the greatest supply and integration of road networks in favor of the former. South America, although historically and structurally, presents significant delays in terms of infrastructure, with connections that are more "out" than "in", and, in view of the accumulation of needs and challenges to date, in recent years it seemed to advance in the physical and territorial integration, in plans and works. Based on the interrelationship between such aspects, this article proposes to discuss the issue of transport during the period 2000-2020, with an emphasis on the policies and investments made and planned, in line with two regional initiatives for physical integration: the Integration of South American Regional

\footnotetext{
1. Doutora em desenvolvimento econômico pela Universidade Estadual de Campinas (Unicamp); mestre em integração da América Latina pela Universidade de São Paulo (USP); e pesquisadora de Pós-Doutorado em Geografia Humana (PPGH) na USP, sobre o papel do Brasil na agenda de projetos infraestruturais do Eixo Amazonas na Amazônia centro-ocidental. E-mail: <thaisvirga@gmail.com>. Orcid: <https://orcid.org/0000-0002-4221-3659>.

2. Doutorando em economia política mundial pela Universidade Federal do $A B C$ (UFABC); e mestre em integração da América Latina pela USP.E-mail: <tomas.marques@ufabc.edu.br>. Orcid: <https://orcid.org/0000-0001-8713-7453>
} 
Infrastructure (Iniciativa para a Integração da Infraestrutura Regional Sul-Americana - IIRSA), from 2000, and the Infrastructure and Planning Council (Conselho de Infraestrutura e Planejamento Cosiplan), from 2009. Specifically, based on a recent diagnosis of the situation of South American infrastructure, the discussion will advance to points of continuity and inflection between such agendas between 2000 and 2016, with a greater focus on Cosiplan. Then, based on a complex political-economic scenario in South America, new conjunctures and prospects about physical integration are presented, indicating a movement of considerable reversal of the infrastructure issue in the subcontinent.

Keywords: physical integration; South America; transport; IIRSA; Cosiplan.

\section{INTEGRACIÓN FÍSICA SUDAMERICANA EN EL PERÍODO RECIENTE (2000-2020): SITUACIÓN, CONTINUIDAD, INFLECCIÓN Y REVERSIÓN}

Ante el proceso de globalización económica y las consiguientes inversiones realizadas para la creación de ejes de conexión que atiendan a la creciente comercialización de productos y servicios y el movimiento de personas, se hacen evidentes en el tiempo y en el espacio las enormes diferencias entre los países desarrollados y los subdesarrollados, lo que conlleva una mayor oferta e integración de las redes viarias a favor de los primeros. Aunque América del Sur presenta importantes retrasos en términos de infraestructura histórica y estructuralmente, con conexiones más "hacia fuera" que "hacia dentro", y en vistas a la acumulación de carencias y desafíos hasta la fecha, en los últimos años pareció avanzar en relación a la integración físico-territorial, los planes y las obras. Partiendo de la interrelación entre estos aspectos, en este artículo se propone discutir el tema del transporte durante el período 2000-2020, con énfasis en las políticas e inversiones realizadas y planificadas, en línea con dos iniciativas de integración física regional: la Iniciativa para la Integración de la Infraestructura Regional Sudamericana (IIRSA), de 2000, y el Consejo de Infraestructura y Planificación (Conselho de Infraestrutura e Planejamento - Cosiplan), de 2009. Concretamente, a partir de un diagnóstico reciente de la situación de la infraestructura de América del Sur, la discusión avanzará los puntos de continuidad e inflexión entre estas agendas entre 2000 y 2016, con un mayor enfoque en el Cosiplan. Luego, con base en el complejo escenario político y económico de América del Sur, se presentan nuevas coyunturas y perspectivas sobre la integración física, lo que indica un movimiento de considerable reversión de la cuestión de la infraestructura en el subcontinente.

Palabras clave: integración física; América del Sur; transporte; IIRSA; Cosiplan.

JEL: N76; F15; 018.

DOl: http://dx.doi.org/10.38116/rtm23art6

Data de envio do artigo: 29/4/2020; Data de aceite: 24/8/2020.

\section{INTRODUÇÃO}

A infraestrutura de transportes comumente é tratada como fundamental a quaisquer processos de integração e de ampliaçẫo das perspectivas de desenvolvimento, seja de uma cidade, de um país, de uma regiáo ou mesmo de um continente. Sua oferta, carência, atualização tecnológica, além do estado de manutençáo de vias e modais, se relacionam a vantagens ou desvantagens no âmbito da economia e do comércio, assim como na criação de condiçóes para o desenvolvimento socioeconômico, especialmente quando reúnem características 
centrais como: conectividade, importando a intermodalidade para ampliar conexôes; capilaridade, articulando redes de transporte e logística visando à redução de tempo de viagens e custos entre origens e destinos; e acessibilidade, ampliando e melhorando acessos, seja a serviços (como educação e saúde em zonas isoladas), seja à circulação de cargas e pessoas. ${ }^{3}$

Reflexionando, inicialmente, o papel dos transportes, se assinala com frequência a debilidade da infraestrutura física da América do Sul, tanto em termos comparativos internacionais, quanto, entre seus próprios países e dentro de cada um desses. O subcontinente é marcado por redes logísticas e de integração que trazem consigo o fardo e a herança de economias historicamente voltadas mais "para fora" que "para dentro". Tal caracterização, associada à alta centralização das atividades produtivas e de serviços, a qual beneficia apenas algumas poucas zonas (particularmente litorâneas e próximas aos principais centros produtores e consumidores), como evidencia Handabaka (2006), reforçaria, portanto, a exclusão e os acessos de outras muitas - na Gran Amazonía (Virga, 2019) e nos rincôes de diversos estados, províncias e departamentos dos países sul-americanos, explicitando desigualdades nas dinâmicas socioeconômicas locais, assim como no processo de desenvolvimento dos países e nas relaçôes entre eles. ${ }^{4}$

Tal situação histórica-estrutural e ainda presente em várias regióes do subcontinente apresentou pontos de continuidade e inflexão no período 2000-2020, com avanços de iniciativas e agendas priorizando uma maior e mais efetiva integração física sul-americana nos primeiros quinze anos e recuando crescentemente nesse ímpeto integracionista nos cinco anos seguintes. Um período marcado por progressos e retrocessos na integração física. Inter-relacionando tais aspectos, este artigo propóe debater sobre a questão dos transportes a partir de 2000, focalizando as políticas e os investimentos efetuados e previstos, baseado em duas principais iniciativas: a Iniciativa para a Integração da Infraestrutura Regional Sul-Americana (IIRSA) de 2000 e o Conselho de Infraestrutura e Planejamento (Cosiplan) de 2009. Com respeito a essas agendas de integração e nessa sequência de mudanças de cenários, referimo-nos especificamente ao seguinte.

1) Estabelecimento da IIRSA em 2000, como um marco de uma agenda consensuada pelos doze países da regiáo voltada a projetos de integraçáo de infraestruturas.

2) Avanços diplomáticos com a constituição da Comunidade Sul-Americana de Naçóes (Casa) em 2004, que, em 2008, se transformaria na União das Naçôes Sul-americanas (Unasul), em meio a um panorama político

3. Checar Vickerman (1974) e Januário (1995).

4. Consultar também Batista (1996), Costa (2010; 2011) e Paz (2011). 
e econômico de chegada ao poder de governos caracterizados como "progressistas" e com discursos favoráveis a uma maior integração no subcontinente.

3) Amadurecimento nas decisóes sobre uma listagem de projetos prioritários e estruturantes para a América do Sul. Em particular, a atuação da IIRSA, que partira de feições megalômanas do ponto de vista de financiamento para uma definição mais enxuta de seus projetos dentro do Cosiplan, como um conselho da Unasul, passando a constituir um foro técnico deste.

4) Progresso de condiçôes e arranjos de financiamento de infraestruturas, com ações concretas de participação de órgãos nacionais e regionais via contribuição de fontes públicas e privadas, fortalecidos, pelo menos até 2016, por mecanismos de concessóes a empresas e conglomerados igualmente regionais ou mesmo globais, viabilizando o aporte necessário de recursos a projetos e algumas execuçóes.

5) Reversão do quadro político e econômico, com o desmembramento e o enfraquecimento das citadas institucionalidades, com a finalização da Unasul em 2019 e, portanto, de seus conselhos, como o Cosiplan. Em especial, com a vitória eleitoral de governos com políticas mais alinhadas a diretrizes neoliberais e conservadoras e com discursos coadunados mais a interesses externos, particularmente estadunidenses, que da própria América do Sul.

Assim, o artigo encontra-se dividido em mais quatro seçóes além desta introdução. A segunda seção apresenta a caracterização da infraestrutura física na América do Sul. Na terceira, o texto discute os pontos de inflexão ou continuidade de agendas da integração de infraestrutura do subcontinente, com base na IIRSA e no Cosiplan, para, na quarta seção, apresentar elementos e reflexóes prospectivas finais, vinculando-os a uma guinada política e econômica nos últimos anos. Enfim, são apresentadas as consideraçôes finais dos autores sobre as transformaçóes na agenda de integração física na América do Sul.

\section{A INFRAESTRUTURA FÍSICA DOS TRANSPORTES NA AMÉRICA DO SUL}

A situação da infraestrutura física da região configura marca e resultado de sua própria história política e socioeconômica, uma história de dependência. Assim, partindo de uma abordagem histórico-estrutural, infere-se que tanto os espaços quanto as redes logísticas de integraçáo na América do Sul e Latina trazem consigo o fardo e a herança de economias historicamente caracterizadas por um perfil agroexportador - e, portanto, prioritariamente voltadas "para fora". Como apontado por Paz (2011, p. 29), as infraestruturas regionais foram submetidas 
aos interesses de determinados setores econômicos, que, somados às barreiras geográficas da cordilheira dos Andes e da região amazônica, constituíram-se como uma estrutura exportadora com pouca ou nenhuma integração entre as nações do subcontinente, dificultando ou impedindo o comércio intrarregional.

Assim, Padula (2011, p. 5) ressalta que o estabelecimento de projetos voltados a uma maior conexão física (transportes, energia e telecomunicaçōes) deve ir além de servir apenas como os chamados corredores de exportação ou viabilizar uma maior projeção internacional da região, também facilitando a mobilidade dos fluxos econômicos entre os territórios dessas naçóes, criando novas oportunidades de integração regional. Gallo (2008, p. 66) aponta que o setor de transportes possui um papel determinante para adensar um processo integracionista na América do Sul, visto que o custo de transporte é comum à produção de qualquer tipo de bem ou serviço.

Nesse sentido, precisa-se de uma infraestrutura que amplie as relações regionais e, ao mesmo tempo, diminua seus iguais e históricos gargalos relacionados - da falta de competitividade internacional e fragilidade do comércio intrarregional à superação da pobreza e do próprio subdesenvolvimento, configura-se um desdobramento fundamental da integração física (Sela, 2011, p. 3).

Dito isso, uma observação alicerce deste artigo refere-se ao lugar da América do Sul no tocante à infraestrutura de transportes, tanto em termos globais quanto em termos alusivos aos principais gargalos e obstáculos internos, dentro e entre seus próprios países.

Quanto à competitividade global, destaca-se o estudo do Banco Mundial (Arvis et al., 2018) que relaciona o Índice de Desenvolvimento Humano (IDH) ao denominado Índice de Performance Logística (Logistics Performance Index - LPI), de escala de 1 a 5 , números respectivos a muito baixo ou muito alto. ${ }^{5}$ Conforme os dados divulgados em 2018, a América do Sul alcançou um LPI de 2,78, tendo dois países da regiấo com média alta (upper middle), Chile e Brasil, e os outros, excetuando a Guiana, com notas na média baixa e baixa, juntamente com países mais subdesenvolvidos de África e Ásia. No entanto, é possível observar uma melhora do LPI sul-americano na comparação com 2007, quando ficou com a pontuação de 2,6. A tabela 1 mostra a situação de cada um desses países, com a maioria daqueles do subcontinente progredindo no ranking, ainda que abaixo de países com integradas infraestruturas intermodais e LPI superior a $4 .{ }^{6}$

5. De modo geral, na metodologia para a elaboração do índice LPI são levados em conta os seguintes parâmetros: alfândega, infraestrutura, embarques internacionais, qualidade e competência logística, rastreamento e acompanhamento e pontualidade. Para mais informações sobre a metodologia do Banco Mundial, assim como os rankings disponíveis, consultar: <https://lpi.worldbank.org/international/global>.

6. Como, em 2018, os mais bem colocados: Alemanha, Suécia, Bélgica, Áustria, Japão, Singapura e outros. 
TABELA 1

Ranking (LPI) de infraestrutura na América do Sul (2018 e 2007)

\begin{tabular}{lcc}
\hline \multirow{2}{*}{ Países } & \multicolumn{2}{c}{ LPI, de 1 a 5 (em ordem decrescente) } \\
\cline { 2 - 3 } & 2018 & 2007 \\
\hline Chile & 3,32 & 3,25 \\
Brasil & 2,99 & 2,75 \\
Colômbia & 2,94 & 2,50 \\
Argentina & 2,89 & 2,98 \\
Equador & 2,88 & 2,60 \\
Paraguai & 2,78 & 2,57 \\
Peru & 2,69 & 2,77 \\
Uruguai & 2,69 & 2,51 \\
Bolivia & 2,36 & 2,31 \\
Guiana & - & - \\
Venezuela & 2,23 & 2,62 \\
\hline
\end{tabular}

Fonte: Arvis et al. (2018).

Elaboração dos autores.

Obs.: Quanto ao Peru, a redução de sua posição no LPI justifica-se pelo alto número de bloqueios logísticos decorrentes de obras de ampliação, duplicação, além de vias novas nos últimos quatro anos (2015-2019), com algumas conclusões de projetos viários remodeladas ou entregues entre o final de 2018 e o início de 2019 e, portanto, não computadas ao último ranking LPI disponível (Virga, 2019).

E se no tocante à competitividade logístico-comercial a América do Sul apresenta um quadro aparentemente melhor no comparativo entre 2018 e 2007, com algumas exceçôes, há importantes problemas compartilhados internamente que aqui devem ser mencionados. Vejamos, a seguir, um breve panorama de sua condição infraestrutural por meio dos quadros 1 e 2: o primeiro apresenta uma sistematização mais técnica-setorial da situação geral da integração física no subcontinente, com base nos principais modais de transporte, e o segundo dá uma ideia mais concreta relativa à oferta infraestrutural, visando a um melhor panorama dos transportes na América do Sul.

Alguns aspectos físico-geográficos e outras complexidades adicionais devem ser destacados.

No que se refere a ferrovias, estas concentram-se no transporte de grandes volumes e peso de cargas de exportaçáo, em especial no Cone Sul (Handabaka, 2006), com o transporte de passageiros escanteado, historicamente, em favor do modal rodoviário. Em ambos os modais, somam-se dificuldades de manutençóes viárias nas zonas úmidas da Amazônia e de traspassamento nos Andes. No primeiro caso, rodovias recorrentemente afundam e são interrompidas - nas zonas de selva alta, ainda são destruídas por constantes desmoronamentos. Quanto a tal traspassamento e à ininterrupção de fluxos, ressalta-se que, se a construção e a operacionalidade de ferrovias em grandes altitudes imprimem vultuosos aportes, 
a manutenção permanente de rodovias naquelas regióes é constantemente comprometida por episódios naturais característicos de selvas úmidas e zonas montanhosas (Virga, 2019).

QUADRO 1

Situação da infraestrutura sul-americana: aspectos e gargalos gerais

\begin{tabular}{|c|c|}
\hline Modal & Situação geral \\
\hline Ferroviário & $\begin{array}{l}\text { A infraestrutura ferroviária apresenta limitações operativas em suas respectivas redes devido à integração } \\
\text { preexistente e ao estado das ferrovias, além da fragilidade das interfases para interconectar redes } \\
\text { ferroviárias com diferentes bitolas, regra geral no subcontinente. }\end{array}$ \\
\hline Aeroviário & $\begin{array}{l}\text { Apesar de os aeroportos terem ampliado a capacidade de transporte de cargas e de passageiros na América } \\
\text { do Sul nos últimos anos, este modal ainda apresenta um alto nível de concentração em áreas litorâneas, } \\
\text { capitais e maiores cidades (Wilmsmeier, 2015), caracterizando pouca integração física e intermodal no } \\
\text { âmbito regional. }\end{array}$ \\
\hline Rodoviário & $\begin{array}{l}\text { Afora sua oferta ser maior entre todos os modais, problemas como falta de integração viária e má } \\
\text { conservação e sinalização são frequentes. Existem situações bastante diversas de oferta e de pavimentação } \\
\text { entre os países da região, podendo ser subdivididas naquelas em que: i) os eixos rodoviários são importantes } \\
\text { e os fluxos de cargas e pessoas estão estabelecidos, }{ }^{-1 i i)} \text { os serviços de transporte nas rodovias foram } \\
\text { iniciados recentemente; }{ }^{-2} \text { e iii) os eixos dos serviços inter-regionais de transporte rodoviário que não foram } \\
\text { sequer estabelecidos. }\end{array}$ \\
\hline \multirow[t]{2}{*}{$\begin{array}{l}\text { Aquaviário } \\
\text { (marítimo e fluvial) }\end{array}$} & $\begin{array}{l}\text { Aqui, o número de rotas, a frequência de serviços oferecidos pelas companhias de navegação e a } \\
\text { operacionalidade de portos e centros logísticos ajudam a compreender a oferta de serviços, esses } \\
\text { dependendo diretamente das características e do nível de conservação da própria rede hidrográfica. } \\
\text { Quanto à rede marítima, as rotas caracterizam a infraestrutura que vincula os portos sul-americanos nas } \\
\text { costas atlântica e pacífica. Os principais portos-pivôs são atendidos por rotas oceânicas e oferecem serviços } \\
\text { diretos ou com transbordos, enquanto os alimentadores (feeders) são atendidos pelos serviços de cabotagem } \\
\text { nacional ou regional e a frequência de serviços está em função do volume de carga que manipulam, o que } \\
\text { reflete a importância da respectiva hinterlândia. }\end{array}$ \\
\hline & $\begin{array}{l}\text { Já quanto ao modal fluvial, este ocorre por meio de um emaranhado de rios e afluentes das bacias do } \\
\text { Amazonas, do Prata e do Orinoco, por onde transitam, operacionalizando com uma quase completa falta } \\
\text { de organização e controle, além de constantes interrupções nas épocas de vazante à maior parte das } \\
\text { embarcações fluviais. Os serviços de transporte fluvial, tanto de cargas como de pessoas, são oferecidos } \\
\text { por embarcações de cada país, além de empresas de diferentes tipos, com comuns e variados gargalos que } \\
\text { impactam diretamente a oferta perene de acessibilidades e fluxos. }\end{array}$ \\
\hline
\end{tabular}

Elaboração dos autores.

Notas: ${ }^{1}$ Com a presença de várias empresas de transporte operando principalmente nos países do Cone Sul, e em muito menor parte na Comunidade Andina de Nações (CAN), sobretudo na fronteira entre Colômbia e Venezuela.

${ }^{2}$ Considerada a maior linha rodoviária do mundo, com $6.035 \mathrm{~km}$ de percurso e com o início de sua operacionalização somente em janeiro de 2016, a Expresso Ormeño configura uma importante empresa de transporte internacional rodoviário, com rotas do Peru para Chile, Colômbia, Bolívia, Equador, Argentina e Venezuela - e mais recente também para o Brasil.

${ }^{3}$ Nesses casos, os serviços são exclusivamente nacionais entre cidades de um mesmo país, com algumas rotas chegando a áreas de fronteira, mas sem interconexão ou maior coordenação, como ocorre em muitos exemplos nos países sul-americanos.

Já no modal fluvial, destaca-se que, além da desorganização e da falta de controle estatal de tráfegos (sobretudo quanto a manifestos de cargas), a existência de inúmeros embarcaderos informais e a consequente expansão de fluxos e negócios ilícitos (como minérios, madeiras, tráfico de animais e drogas) conferem obstáculos adicionais. 


\section{QUADRO 2}

\section{Oferta infraestrutural sul-americana: principais modais}

\begin{tabular}{|c|c|}
\hline Modal & Situação geral \\
\hline Ferroviário & $\begin{array}{l}\text { Segundo dados disponibilizados pela Union Internationale des Chemins de Fer (UIC) em seu portal, }{ }^{1} \text { entre os } \\
\text { principais países com maior oferta, segundo as extensões de redes ferroviárias em operação, destacam-se Brasil } \\
\text { (37.743 km, dado de 2014), Argentina ( } 36.966 \text { km, 2008) e Chile (5.898 km, 2006). A seguir, vêm Bolivia } \\
\text { (2.866 km, 2007), Peru (2.020 km, 2008, principalmente devido à ferrovia central andina) e Colômbia (1.663 km, } \\
\text { 2007). Todos com diversos trechos inativos e evidenciando uma grande diferença de oferta entre os países. }\end{array}$ \\
\hline Aeroviário & $\begin{array}{l}\text { Segundo dados de } 2015 \text { do World Airport Traffic Report (ACI, 2015), no referido ano, existiam mais de } \\
7.500 \text { aeroportos em funcionamento na América do Sul, sendo os de Brasil, Argentina e de outras capitais os } \\
\text { de maior movimentação. Ainda, segundo matéria até então vinculada pela Secretaria Nacional de Aviação } \\
\text { Civil do Brasil em 2014, }{ }^{2} \text { apesar do crescimento e da potencialidade de maior ampliação, o subcontinente } \\
\text { permanece pouco conectado, com a oferta de assentos e a capacidade de cargas concentradas em apenas } \\
\text { quatro empresas (Latam, Avianca, Aerolíneas Argentinas e Gol), e com } 80 \% \text { da oferta e poucos voos } \\
\text { regulares fora das capitais e regiões metropolitanas. }\end{array}$ \\
\hline Rodoviário & $\begin{array}{l}\text { Consoante às últimas informações do relatório The World Factbook, }{ }^{3} \text { destaca-se uma maior oferta de } \\
\text { rodovias pavimentadas no Cone Sul que no "Grupo Andino" }{ }^{4} \text { No primeiro caso, com cerca de } 2,6 \text { milhões de } \\
\text { quilômetros de rodovias, dos quais } 2 \text { milhões são concentrados apenas no Brasil (dados, por país, referentes de } \\
2010 \text { a 2018), a taxa média de pavimentação chega a 78,3\%. Já no Grupo Andino (com menos informações } \\
\text { oficiais disponibilizadas pelos países e dados de } 2012 \text { a 2017), de cerca de } 577.000 \text { km (concentrados na } \\
\text { Colômbia e no Peru - } 347.000 \text { km), estima-se que apenas próximo de } 20 \% \text { das rodovias sejam pavimentadas. }\end{array}$ \\
\hline $\begin{array}{l}\text { Aquaviário } \\
\text { (marítimo e fluvial) }\end{array}$ & $\begin{array}{l}\text { No caso marítimo, conforme ranking da Comissão Econômica para a América Latina e o Caribe (Cepal) } \\
\text { de } 2017^{5} \text { sobre o movimento de cargas em contêineres em ambas as regiões, de } 120 \text { portos, apenas } \\
\text { dois apresentam profundo calado, permitindo o atracamento de navios de maior capacidade de carga e } \\
\text { tonelagem: os de Santos (Brasil) e Buenos Aires (Argentina). Handabaka (2006, p. 225, tradução nossa) } \\
\text { reforça que a maioria dos terminais marítimos do subcontinente se caracteriza por portos-pivôs regionais } \\
\text { ou sub-regionais, já que muitos "não têm ligação direta com os corredores interoceânicos e globais", dado } \\
\text { que é o canal do Panamá que possui o papel determinante nas principais rotas mundiais que fazem escalas } \\
\text { em portos sul-americanos em ambas as costas (pacífica e atlântica). Já no caso fluvial, apesar de uma rede } \\
\text { hidroviária abrangendo uma área próxima a } 11 \text { milhões de quilômetros quadrados (conformada pelas } \\
\text { bacias do Amazonas, do Prata e do Orinoco) e totalizando uma longitude navegável próxima a } 108.000 \text { km } \\
\text { (Handabaka, 2006), apenas cerca de 3,3 mil quilômetros constituem trechos aptos à navegação de navios } \\
\text { oceânicos e embarcações de maior dimensão). }\end{array}$ \\
\hline
\end{tabular}

Elaboração dos autores.

Notas: ${ }^{1}$ Disponivel em: <https://uic.org/latin-america/>

2 Atualmente disponível em: <https://www.gov.br/infraestrutura/pt-br/assuntos/transporte-aereo/noticias-aviacao/ aviacao-cresce-na-america-do-sul-mas-integracao-e-baixa-diz-bid>

${ }^{3}$ Disponivel em: <https://www.cia.gov/library/publications/the-world-factbook/fields/385.html>.

${ }^{4}$ Cone Sul: Brasil, Argentina, Chile, Uruguai e Paraguai. Grupo Andino: Bolívia, Peru, Equador, Colômbia e Venezuela.

${ }^{5}$ Disponível em: <http://bit.ly/2wKRD1Y>.

${ }^{6}$ Alertando a relevantes fragilidades das vias fluviais no subcontinente ao comércio regional e global, o autor aponta os investimentos infraestruturais necessários a diversos trechos da rede fluvial sul-americana, por meio de: dragagem de canais de navegação e de acessos aos portos, visando a um melhor trânsito fluvial; balizamento de cursos fluviais para maior segurança e perenidade de navegação tanto de dia quanto à noite; canalização de meandros com o objetivo de controlar os processos de sedimentação e, assim, manter o calado; e construção de eclusas em algumas represas para permitir a continuidade da navegação (Handabaka, 2006, p. 47-48). No âmbito mais local dos fluxos e acessos, adiciona-se a necessidade de maiores sinalizações, limpeza de troncos e cascos submersos, dragagem de pequenos baixios e derrocamento de pedras, como observa Nazaré (2001) ao caso amazônico e, ainda, chamando a atenção: "É isso que faz a diferença de um rio para uma hidrovia" (op. cit., p. 83).

Além disso, e conforme antes apontado, é notável a maior oferta intermodal nas zonas litorâneas, assim como nos entornos metropolitanos, capitais administrativas e localidades mais desenvolvidas de cada um dos países sul-americanos. Em trabalho desenvolvido por mais de dez anos, Handabaka (2006) apresenta mapas que explicitam o quão concentrada era a infraestrutura de transportes da região naquele momento, e o quanto algumas porçóes não são 
servidas "efetivamente" por qualquer um dos principais modais de transportes, seja por falta de oferta de malhas ou, como no caso aquaviário, por problemas à manutenção de conectividades e acessibilidades perenes.

Os mapas 1, 2 e 3 evidenciam as redes ferroviária, rodoviária e fluvial da América do Sul, conforme últimas atualizaçôes, em âmbito subcontinental, realizadas por Handabaka (2006).

Assim, com foco no questionamento central aqui proposto acerca dos avanços e/ou continuidades tocantes à integração física no subcontinente, analisaremos, a seguir, as agendas recentes dessa integração, particularmente a IIRSA e o Cosiplan, em um panorama de mudanças relevantes no cenário político e econômico do subcontinente.

MAPA 1

\section{Rede ferroviária sul-americana (2006)}

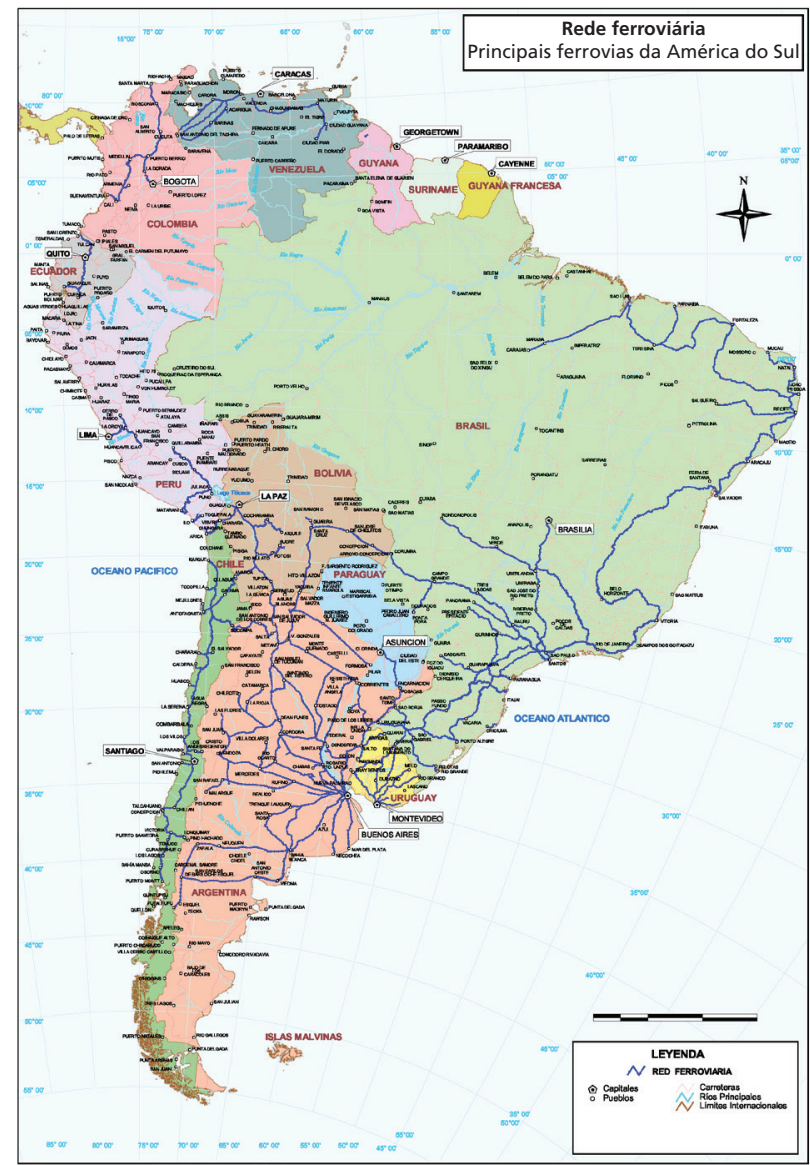

Fonte: Handabaka (2006)

Obs.: Figura reproduzida em baixa resolução e cujos leiaute e textos não puderam ser padronizados e revisados em virtude das condições técnicas dos originais (nota do Editorial). 
MAPA 2

Rede rodoviária sul-americana (2006)

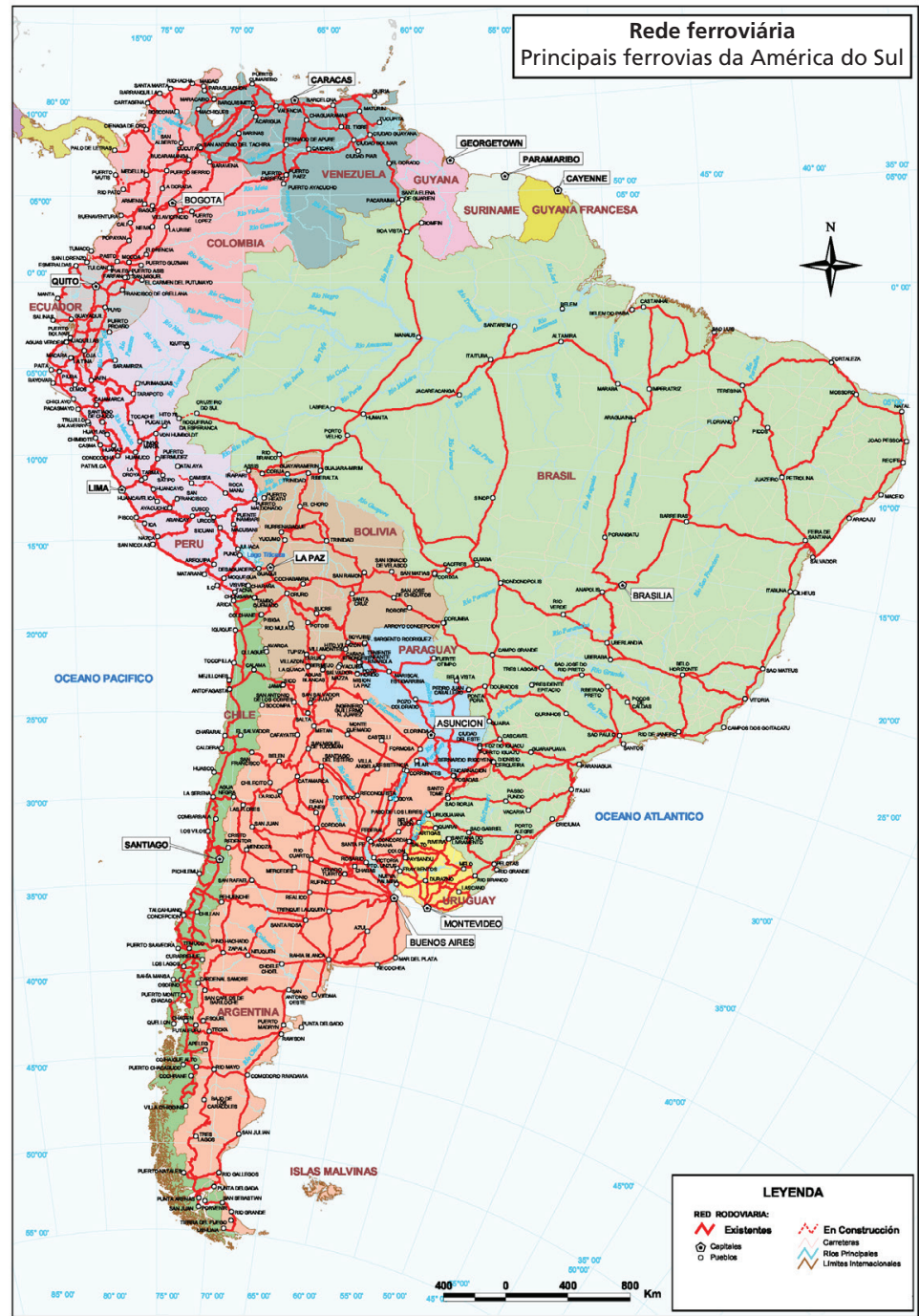

Fonte: Handabaka (2006).

Obs.: Figura reproduzida em baixa resolução e cujos leiaute e textos não puderam ser padronizados e revisados em virtude das condições técnicas dos originais (nota do Editorial). 
A Integração Física Sul-Americana no Período Recente (2000-2020): situação, continuidade, inflexão e reversão

\section{MAPA 3}

Rede fluvial sul-americana e principais portos

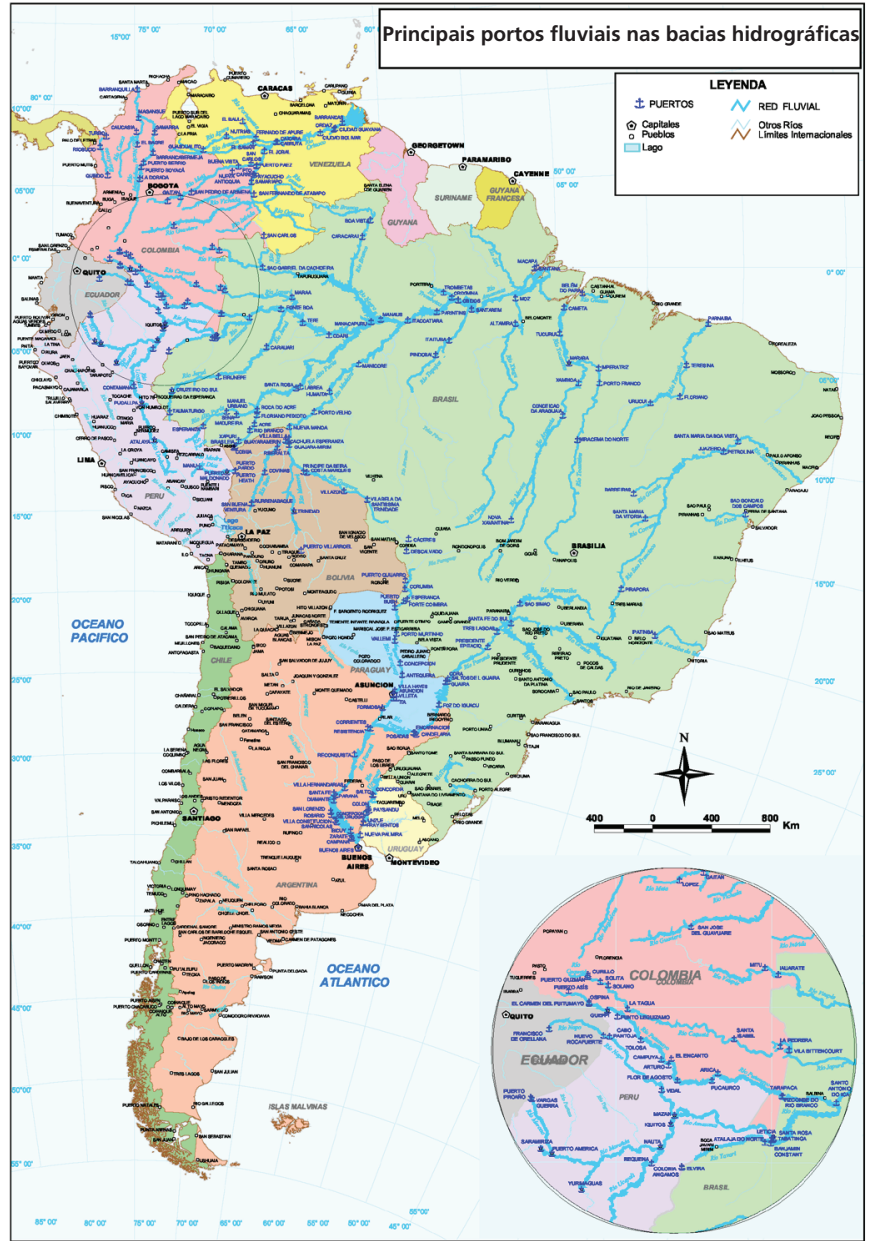

Fonte: Handabaka (2006).

Obs.: 1. Figura reproduzida em baixa resolução e cujos leiaute e textos não puderam ser padronizados e revisados em virtude das condições técnicas dos originais (nota do Editorial).

2. Destaque de Handabaka (2006) à Amazônia centro-ocidental, região fronteiriça entre Brasil, Colômbia, Equador e Peru, sobre a qual se relacionam muitos projetos do Eixo Amazonas da IIRSA e do Cosiplan (Virga, 2019).

\section{IIRSA E COSIPLAN: PONTO DE INFLEXÃO OU CONTINUIDADE DA INTEGRAÇÃO FÍSICA NA AMÉRICA DO SUL?}

Com a população estimada em 425,6 milhóes de habitantes em 2019, segundo The World Factbook, o conjunto de países da América do Sul apresentou na primeira década do novo século um crescimento econômico acima da média mundial, ${ }^{7}$

7. Entre 2002 e 2010, de acordo com dados do Banco Mundial, a região obteve um crescimento de 5,3\% ao ano, enquanto a média mundial, no mesmo período, foi de 3,9\%. 
catalisado pelo chamado boom das commodities, alavancando as exportaçóes da região. Nesse contexto, as políticas e agendas de integração infraestrutural ganharam proeminência configurando uma espécie de nova orientação para a ação do setor público dos países do subcontinente, trazendo novos esforços em estratégias de planejamento que atendessem não apenas aos atuais fluxos de pessoas, bens e serviços entre localidades produtoras e seus mercados, no tocante ao comércio exterior a outros continentes, mas também aos fluxos regionais.

E se é certo que a história do subcontinente fora marcada por velhas idealizações quanto à ampliação da infraestrutura física como passo inicial aos objetivos de integração regional, ${ }^{8}$ é possível inferir que foi a partir dos anos 2000 que esse objetivo tomou forma e apresentou resultados, em termos de planos e na exequibilidade de obras. Assim, analisam-se nesta seção duas importantes iniciativas de integração física regional: a IIRSA e o Cosiplan. Ambos com agendas que, desde a institucionalização de projetos intranacionais e transfronteiriços da infraestrutura, evoluíram em matéria de coordenação legal, técnica, administrativa e financeira, incorporando tal perspectiva aos planos nacionais de desenvolvimento, assim como vislumbrando o fortalecimento de relaçóes entre os países da região.

\subsection{Uma agenda de integração física regional: a IIRSA}

Durante a primeira reuniâo de presidentes da América do Sul, na I Cúpula de Países da América do Sul realizada em Brasília, em agosto de 2000, surgiu a iniciativa da IIRSA, como um mecanismo institucional voltado à coordenação de açôes intergovernamentais para a construção de uma agenda comum de fortalecimento de infraestruturas econômicas entre os doze países da regiáo. Tal iniciativa partiu do então presidente brasileiro naquele ano, Fernando Henrique Cardoso (FHC), anfitrião do encontro que, de acordo com Virga (2019, p. 129) "tratou de fazer com que o documento de apoio à discussão, enviado para o BID [Banco Interamericano de Desenvolvimento] meses antes do encontro, fosse bem recebido pelos presidentes dos outros países e não tomado como uma imposição por parte do maior país da região". Pares (2006) observa que a iniciativa também fora apoiada imediatamente pelo Peru. Ao final dessa primeira reunião, ambos os países cuidaram de impulsionar a iniciativa.

Pela primeira vez, projetos passariam a ser estudados e planejados de forma conjunta e com um mesmo foco: a ampliação e a modernização da infraestrutura na América do Sul, nas áreas de energia, transporte e comunicaçóes. Orientada

8. Consultar Figueiredo (2015). 
por eixos de integração e desenvolvimento, ${ }^{9}$ a IIRSA objetivou avançar em melhoramento e ampliação de aeroportos; construção e ampliação de malhas ferroviárias e rodoviárias; modernização fluvial e portuária; ligação de linhas de transmissão; e estabelecimento e regulação de fronteiras.

Com esse intuito, em termos de aportes necessários e financiamentos, a iniciativa acabou por promover a articulação entre governos, bancos governamentais, instituiçóes financeiras multilaterais e o setor privado. Além do aval dos governos dos doze países da América do Sul, ressaltam-se as três principais instituiçóes multilaterais da regiáo envolvidas mais diretamente com a IIRSA com foco em apoios técnicos: BID, Corporação Andina de Fomento (CAF) e Fundo Financeiro para o Desenvolvimento da Bacia do Prata (Fonplata). Quintanar e López (2003) atentariam que tais instituiçôes permitiram aos países da regiáo mobilizar recursos maiores que outras fontes tradicionais, como o Banco Mundial, o qual exige condicionantes de ajustes políticos e fiscais.

Outro relevante suporte à estruturação da IIRSA diz respeito aos denominados processos setoriais de integração (PSIs), identificando obstáculos normativos e institucionais que impediam o desenvolvimento da infraestrutura no subcontinente, indicando direcionamentos. Entre os principais PSIs, destacam-se, além de instrumentos de financiamento de projetos de integração física e energética, ${ }^{10} \mathrm{a}$ facilitação de pontos de fronteira e tecnologias de informação e comunicação. Dessa forma, a iniciativa receberia apoio organizacional em cada país, operando a partir de fóruns ad hoc, imprimindo que decisóes deveriam ser tomadas por consenso. Assim, a IIRSA caracterizaria uma estratégia de hub, de acordo com Moreira (2007), com atuação orientada a: robustecer a capacidade de governos em planejar e coordenar investimentos; padronizar ou harmonizar aspectos regulatórios e normativos na operação da infraestrutura e nos fluxos de comércio exterior; e gerar uma carteira de projetos atrativos para o setor privado, coordenando, institucionalmente, novos mecanismos de financiamento articulados entre diferentes instâncias.

Quanto à sua estrutura institucional, a IIRSA foi inicialmente dirigida pelo Comitê de Direção Executiva (CDE), composto por ministros de infraestrutura e planejamento dos países participantes, com o objetivo de nortear açóes, acordadas as prioridades dos próprios governos, discutidas em reunióes anuais, como observa Padula (2014). Abaixo do CDE estava o Comitê de Coordenaçáo Técnica (CCT),

9. Inspirados nos Eixos Nacionais de Integração e Desenvolvimento (Enids) lançados no contexto do Plano Brasil em Ação em 1996. Sobre isso, Becker (1999, p. 29) apontaria à "retomada de uma estratégia territorial nacional, após mais de uma década de imobilismo", fundamentada em um macrozoneamento ampliado em necessidades externas e internas (produtivas e quanto ao papel do Estado). Ver também Théry e Mello (2009). Ideias essas de planejamento nacional que, então, conformariam uma base ao estabelecimento da IIRSA em âmbito regional.

10. Incluindo sistemas operativos de transporte aéreo, marítimo e multimodal. 
órgão executivo formado pelas três entidades de fomento (BID, CAF e Fonplata), e estudos e análises ficavam a cargo dos Grupos Técnicos Executivos (GTEs), divididos em processos setoriais e eixos de integração e desenvolvimento (EIDs). Ademais, foram criadas coordenaçóes nacionais com o objetivo de organizar o intercâmbio entre os países e articular os diferentes órgãos envolvidos da IIRSA em cada país.

Quanto aos EIDs, notou-se um importante avanço de planejamento com a IIRSA, visto que tais eixos foram alicerçados às infraestruturas logísticas previamente existentes na regiáo. Partindo da multimodalidade dos transportes com suas respectivas áreas de influência, cada eixo foi conformado e articulado às redes de energia e telecomunicaçóes, buscando maior sinergia entre os segmentos infraestruturais.

Assim, durante os primeiros estudos conjuntos, a situação infraestrutural sul-americana, sua oferta e a articulaçâo de malhas e modais em cada um dos países da regiáo foram caracterizadas, gerando um maior conhecimento sobre dessas condiçóes pelos próprios países. Logo, evoluiu-se à fase de debates e proposiçóes sobre projetos que indicassem melhorias e ampliação da oferta infraestrutural na regiāo.

Neste ponto, a partir de uma "metodologia indicativa de planejamento territorial", conformou-se uma carteira de EIDs, além de projetos organizadores do território sul-americano, contando, inicialmente, com mais de quinhentos projetos e com investimentos previstos em quase US\$ 100 bilhóes, uma meta considerada audaciosa por alguns autores tanto pelo número de projetos quanto pelos compromissos (de gastos e investimentos) de cada país.

Durante a terceira reunião dos presidentes da América do Sul em Cuzco, em 2004, foi definida a Agenda de Implementação Consensual (AIC) 2005-2010, formada por projetos prioritários de maior centralidade à ampliação da integração física, sendo propostos 31 projetos prioritários ${ }^{11}$ com investimentos estimados em cerca de US\$ 7 bilhôes. Essa decisão aparece como um significativo avanço no comparativo histórico das tentativas de planejamento em nível regional, haja vista uma extensa lista de acordos de integração não cumpridos, conforme discute Araujo (2012).

A partir de diagnósticos e ações espacialmente referenciados, os EIDs tinham como objetivo integrar economias nacionais e melhor articulá-las em âmbito sul-americano - e, a partir daí, aos mercados internacionais. Foram lançados dez EIDs na IIRSA (figura 1) com base na identificaçấo de

11. Desse total de 31 projetos da AIC, 16 caracterizavam como de âmbito nacional, 12 binacionais, 1 trinacional e 2 regionais no segmento de telecomunicações. 
requerimentos de infraestrutura física pelos países envolvidos em cada eixo, sendo: Andino (1), Andino do Sul (2), Capricórnio (3), Hidrovia Paraguai-Uruguai (4), Amazonas (5), do Sul (6), Interoceânico Central (7), Mercado Comum do Sul (Mercosul)-Chile (8), Peru-Brasil-Bolívia (9) e Escudo Guianês (10). Tais são caracterizados, respectivamente, pelo seguinte.

- 1: a área de influência abrange os principais "nós" de articulação e cidades de Bolívia, Colômbia, Equador, Peru e Venezuela, articulando-se ao Eixo Amazonas do sul da Colômbia ao norte do Peru, abrangendo toda a área equatoriana.

- 2: o eixo foi concebido como uma franja de território envolvendo algumas regióes da Argentina e do Chile, cuja fronteira é separada pela cordilheira dos Andes em área. Ele se articularia ao norte com o Eixo Andino e, transversalmente, possui áreas de superposição aos eixos 3, 7 e 8, conformando um espaço bioceânico.

- 3: possui como área de influência o entorno do Trópico de Capricórnio, onde nos extremos estão localizadas importantes instalações portuárias nos oceanos Atlântico e Pacífico.

- 4: eixo definido territorialmente a regióes de Argentina, Bolívia, Brasil, Paraguai e Uruguai vinculadas diretamente aos rios Paraguai, Paraná, Tietê e Uruguai.

- 5: definido por meio da delimitação da Amazônia sul-americana, particularmente no lado centro-ocidental, com projetos em áreas amazônicas de Colômbia, Equador, Peru e Brasil.

- 6: eixo de caráter comerciale bioceânico abrangendo instalaçóes portuárias nos oceanos Atlântico e Pacífico, em áreas de Argentina e Chile.

- 7: atravessando transversalmente a América do Sul, vincula portos dos oceanos Atlântico e Pacífico por meio de "nós" de articulação entre Peru, Chile, Bolívia, Paraguai e Brasil.

- 8: o eixo abrange os principais centros econômicos e portos entre Chile, Argentina, Paraguai, Uruguai e Brasil.

- 9: incorpora a vinculação de "nós" em torno da tríplice fronteira entre Peru, Brasil e Colômbia. Esse eixo também se articula ao Eixo Amazonas na área peruana.

- 10: eixo que envolve áreas de Brasil, Guiana, Suriname e Venezuela, como uma importante área estratégica a Caribe e América Central. 
FIGURA 1

Os EIDs da IIRSA

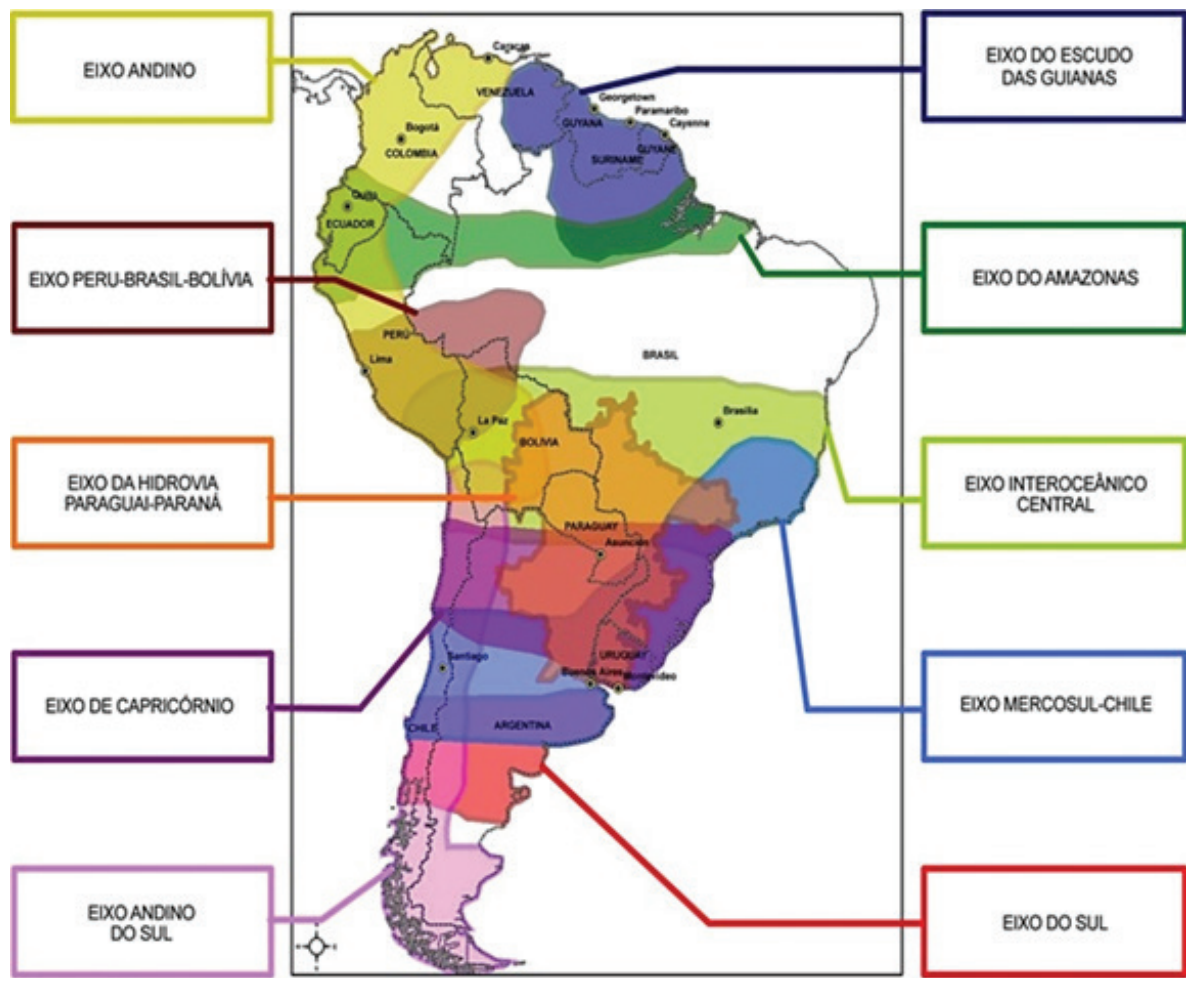

Fonte: GeoSUR.

Obs.: Figura cujos leiaute e textos não puderam ser padronizados e revisados em virtude das condições técnicas dos originais (nota do Editorial).

Destacam-se dois aspectos norteadores do portfólio, sendo o primeiro a atratividade dos investimentos necessários com o interesse também do setor privado em sua execução, levando em conta o montante estimado e a baixa disponibilidade de recursos públicos de origem fiscal no começo dos anos 2000. Indicando uma postura pragmática e servindo a um planejamento indicativo acordado por todos os países da região, o setor privado se tornaria um elemento catalisador fundamental para estabelecer as parcerias para a implementação dos EIDs na agenda AIC da IIRSA.

O segundo aspecto refere-se ao reconhecimento de que o programa de investimentos da IIRSA não englobaria todos os aportes necessários aos países, e sim aqueles estruturantes e capazes de impulsionar outros investimentos em regióes e países onde estão inseridos, primeiramente aumentando as conexóes entre as localidades mais e menos desenvolvidas, de acordo com cada eixo. Ainda assim, a proposta da IIRSA envolveria problemas de interesses a "que" ou "quem" serviria a própria viabilização da agenda de investimentos previstos. 
Vitte (2009, p. 13) já alertava que a IIRSA favoreceria as privatizaçóes e alteraçôes de fluxos, devido aos conflitos de interesses envolvidos em projetos infraestruturais, podendo impactar negativamente o meio ambiente e as populaçōes. ${ }^{12}$ Assim, Quintanar e López (2003) reforçam que, mesmo a IIRSA sendo uma iniciativa desejável dentro do possível, a criaçáo de objetivos comuns entre governos, empresas e instituições financeiras multilaterais leva ao inevitável conflito de interesses entre as partes, que possuem visóes perspectivas diferentes dos projetos. Ressalta-se, portanto, a centralidade do papel Estado na condução e na intervenção na implementação dos projetos a fim de que estes estejam em acordo com uma visão estratégica sul-americana, ainda que os retornos financeiros não sejam suficientemente atrativos para o setor privado.

De acordo com o observado pelos autores, e ao analisarmos dados da própria IIRSA quanto ao financiamento da infraestrutura em sua carteira de projetos prioritários (AIC), atenta-se que cerca de $62 \%$ dos aportes necessários ficariam a cargo dos governos sul-americanos; $21 \%$, da iniciativa privada; e $17 \%$, de instituiçóes financeiras como BID, CAF e Banco Nacional de Desenvolvimento Econômico e Social (BNDES). Dessa forma, para minimizar danos e impactos negativos socioambientais e a possibilidade de riscos financeiros representarem encargos e ameaças adicionais ao setor público, os Estados nacionais devem manter os direcionamentos e as definiçóes de projetos infraestruturais. Assim, Vitte (2009, p. 15) coloca que o Estado deve articular o ordenamento territorial e o processo de implementação de planos em seus diferentes graus e escalas, buscando garantir a preservação ambiental e a participação de agentes regionais e da sociedade civil.

Destaca-se que a criação da IIRSA se deu em uma conjuntura de consolidação das políticas neoliberais na América Latina. Destarte, o foco dos investimentos da iniciativa seria voltado a beneficiar o setor comercial, buscando ampliar a competitividade e diminuir suas vulnerabilidades, trazendo "à cena a necessidade de adaptar a estrutura de circulaçáo às novas demandas da economia internacional" (Vitte, 2009, p. 2). Para além dessa escala, Galvão e Brandão (2003, p. 194) discutem, também criticamente, a ideia de grandes obras de infraestrutura, como de transporte e energia, capacitando a valorização de empreendimentos existentes em seu entorno e a promoção de novos dinamismos econômicos.

Sob outro ponto de vista, Pares (2006) reforça que o lançamento de eixos de integração no contexto sul-americano em grandes espaços ou franjas evidenciou certo planejamento territorial, podendo viabilizar uma maior articulação geoeconômica do subcontinente. $\mathrm{O}$ autor atentava à importância de

12. Para outros textos com visão crítica quanto à lógica capitalista da infraestrutura e à IIRSA, consultar também: Carrion e Paim (2006) e Ceceña, Aguilar e Motto (2007). 
não confundir eixos com "corredores de transporte", pois os primeiros valorariam elementos de planejamento em fluxos de diversos tipos - mercadorias, serviços, pessoas e capitais - entre territórios.

Assim sendo, sem deixar de apresentar algumas críticas à iniciativa, procurou-se não diminuir a importância da IIRSA como uma primeira ação de âmbito regional, em que tanto seu lançamento quanto os próprios EIDs indicavam uma agenda política consensuada pelos doze países sul-americanos, um fato inédito na história do subcontinente.

\subsection{0 avanço da integração física sul-americana entre 2003 e 2016: da Casa ao Cosiplan}

Oficializada em 2004, a Casa buscara institucionalmente a ampliação do diálogo político, o fortalecimento da integração infraestrutural, o estabelecimento de mecanismos financeiros sul-americanos e a promoção da coesão social (inclusão e justiça sociais), conformando uma agenda de visão mais ampla em meio à integração regional em curso. Sua fundação se deu como desdobramento da AIC, reafirmando um passo adiante na integração regional. A Casa se transformaria na Unasul, composta também pelos mesmos doze países, com seu Tratado Constitutivo firmado em maio de 2008 na III Cúpula de Chefes de Estado, realizada em Brasília. Na ocasião, foram decididas a instalaçáo de sua sede em Quito, no Equador, e a criação do Parlamento Sul-Americano em Cochabamba, na Bolívia, e do Banco do Sul, em Caracas, na Venezuela.

Como uma nova organização institucional, ficaria ainda mais claro o objetivo de ampliar a agenda de integração com a Unasul, propondo fortalecer continuamente o processo integracionista na América do Sul por meio da ampliação do diálogo político entre os Estados constitutivos. ${ }^{13}$ Assim, a Uniáo focalizaria uma agenda de integração, a fim de dirimir assimetrias entre os países.

Para isso, a Unasul apresentou uma estrutura organizacional mais extensa e abrangente que a IIRSA, constando de um presidente pro tempore (com mandato de um ano pelo chefe de Estado de um dos países-membros), uma secretaria-geral, um parlamento e um banco, além de dez conselhos ministeriais e setoriais temáticos. Tais conselhos foram os de: Chefes de Estado e de Governo; Ministros de Relaçóes Exteriores; Delegados; Desenvolvimento Social; Combate ao Tráfico de Drogas; Saúde Sul-Americano; Educação, Cultura, Ciência, Tecnologia e Inovação; Energético Sul-Americano; Economia e Finanças; e o de nosso interesse, o Cosiplan.

13. Mariano (2014) destaca, por exemplo, que a criação da Unasul buscou também atrair uma participação mais ativa da Venezuela, país que, até então, reagia ao caráter mais comercial da IIRSA. 
Criado em 2009 e com o estatuto aprovado em junho de 2010, o Cosiplan configurou-se como um importante marco na articulação no subcontinente, responsável pela integração da infraestrutura regional. Entre suas atribuiçôes, destacam-se a identificação de atividades, obras e projetos de interesse comum entre dois ou mais países e uma ampla avaliação das formas de financiamento. Em 2011, a agenda do IIRSA foi passada ao Cosiplan, como apoio no planejamento. No conselho, foram incorporados os trabalhos realizados em dez anos pelo CDE da IIRSA, sendo extinto e passando a constituir seu foro técnico. Ainda nesse ano, após a II Reunião Ministerial do Cosiplan, realizada em Brasília, foi aprovado o chamado Plano de Ação Estratégico (PAE) 2012-2022, no qual foi instituída uma Agenda de Projetos Prioritários de Integração (API), em substituição à AIC da IIRSA. Tal plano e agenda passariam a orientar as decisóes do conselho anualmente.

O processo de definição da API iniciou-se por meio da revisão dos projetos dos EIDs. Apesar de a API ter mantido boa parte dos critérios indicativos de planejamento territorial da AIC, incorporou novos objetivos levando em conta, por exemplo, estudos de conservaçáo histórica e ambiental das regióes por onde passariam os eixos e projetos de transporte propostos. Após a análise de diversos critérios, como a formação de redes de conectividade de alcance regional e açốes complementares, chegou-se à estruturaçáo de uma agenda com nove eixos de integração, mantendo os nomes da IIRSA, com a mudança do Eixo Andino do Sul, que teve parte de seus projetos incorporada ao Eixo Andino.

Analisando setorialmente a agenda de integraçáo física regional no Cosiplan, em 2016, cerca de $90 \%$ dos projetos de infraestrutura referiam-se ao setor de transportes, enquanto $9 \%$ referiam-se à área de energia e $1 \%$, a projetos no setor de telecomunicação. Com uma carteira total de 582 projetos individuais, 519 eram do setor de transportes, com maior participação dos modais rodoviário (49,8\% dos projetos) e fluvial (14,7\%). A tabela 2 especifica os países envolvidos em cada eixo, o número de projetos, fases, tipos e fontes de financiamento.

No que diz respeito ao progresso de execução das obras propostas ao longo do período 2000-2016 e para a conformação e a verificação de andamento dos projetos totais do Cosiplan e dos relativos à API, as secretarias técnicas, juntamente com os governos dos países pertencentes a cada EID, classificaram tais projetos em quatro fases: perfil, pré-execução, execução e concluído.

A primeira etapa (perfil) refere-se ao modelo de negócios dos projetos de infraestrutura, com a identificação de oportunidades ou demandas por um projeto, envolvendo, inclusive, a participaçáo de agentes do setor privado. É nesta fase que se tem a formalização do escopo e a análise de disponibilidade de recursos financeiros e produtivos. 


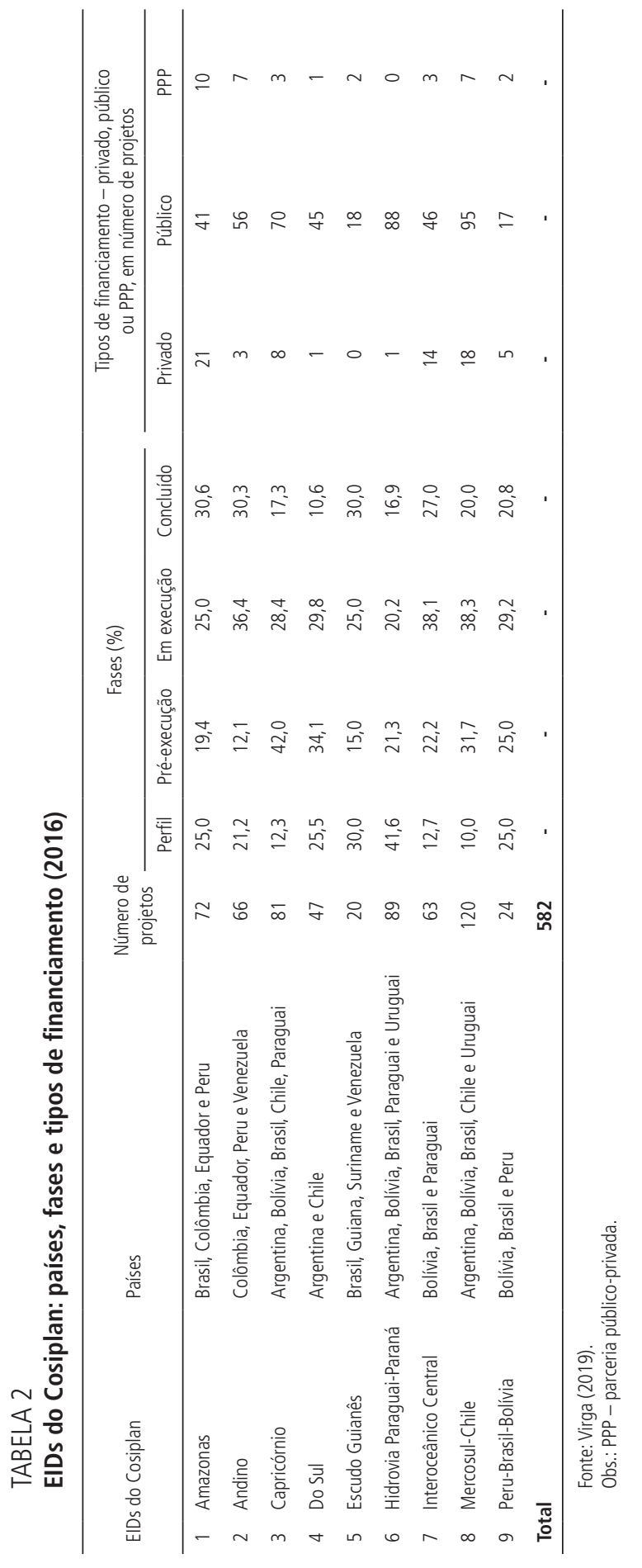


A segunda etapa (pré-execução) prevê estudos de factibilidade, além da elaboração do projeto básico, com a análise de potencialidades e impactos socioeconômicos e ambientais e das respectivas licitaçóes.

Já a terceira etapa (execução) refere-se à operacionalização das obras, em que o projeto é posto em prática, com sua execução e reformulação. Por fim, a última fase constitui a finalização dos projetos, a etapa de conclusão.

Dos 582 projetos individuais em 2016, 21,1\% se encontravam na fase de perfil, $26,1 \%$ em pré-execução, $30,6 \%$ em execução e $22 \%$ estavam concluídos. Desses últimos, totalizando 128 projetos, 56 referiram-se ao segmento de transporte rodoviário, 17 à interconexão energética, 12 a transporte fluvial e 11 a postos de fronteira.

Passando à análise da API resultante dos trabalhos realizados durante 2011, foram restabelecidos 31 projetos estruturantes, divididos em 88 projetos individuais, ${ }^{14}$ com a previsão de investimentos de US\$ 13 bilhóes. O fechamento dessa lista, após o consentimento dos doze países sul-americanos, parecia reafirmar certa coesão política e econômica no subcontinente no tocante a prioridades comuns para o desenvolvimento da regiáo.

Em comparação à AIC da IIRSA, Araujo (2012) observa maior articulação e complementaridade logística, especialização nos trabalhos, atualizaçóes mais recorrentes da evolução dos projetos e, consequentemente, maior disponibilidade de informaçóes, resultando na melhor estruturaçáo e execução dos projetos.

Dos 88 projetos individuais inicialmente previstos em 2011, foram acrescentados mais 15 até o final de 2016, totalizando 103 projetos individuais. Tal ampliação resultou da adição de projetos do Eixo Hidrovia Paraguai-Paraná, considerados de alta relevância a uma maior integração no Cone Sul. Com o maior tempo de estudos e discussóes nas fases iniciais dos projetos no âmbito do Cosiplan, muitas das obras de infraestrutura complexificaram-se, assim como ficou evidente a necessidade por maiores aportes financeiros.

Ainda assim, é possível perceber que os trabalhos se ampliaram e os projetos andaram entre 2013 e 2016. Comparativamente, até outubro de 2013, os projetos na API encontravam-se da seguinte maneira: $21,8 \%$ em perfil, $59,1 \%$ em pré-execução, 19,8\% em execução e 6,9\% concluídos. Ao final de 2016, tais percentuais, respectivamente, passaram a: $17,5 \%, 35 \%, 31,1 \%$ e $16,5 \%$, totalizando, em números, 18, 36, 32 e 17 projetos em cada fase, sinalizando uma visível melhora na execução dos projetos da API, em todas as fases, em menos de três anos. Durante os seis anos da AIC da IIRSA (2004-2010), apenas 0,15\% 
dos projetos prioritários de sua carteira se encontravam concluídos, somando exatamente dois projetos e cerca de $45 \%$ estavam em execução (catorze projetos).

Quanto à questão do financiamento, assim como dos interesses em jogo entre os setores público e privado, conforme apresentado na tabela 2, na carteira total de projetos do Cosiplan até 2016, constata-se uma maior participação do setor público como a principal fonte de financiamento, correspondendo a cerca de $61 \%$ dos investimentos estimados. Em seguida, tem-se 20\% de financiamentos por meio de PPPs e $19 \%$ pelo setor privado.

Especificamente na análise da carteira de projetos prioritários da API, o setor público passou a ter uma participação ainda mais relevante no setor de transportes, financiando cerca de $75 \%$ dos investimentos, seguido do setor privado (15\%) e das PPPs (10\%). Já quanto ao setor de energia, mais de 50\% dos recursos, até 2016, foram viabilizados por meio de PPPs. Nessa esfera, é importante destacar o papel dos respectivos Tesouros Nacionais na execução dos projetos da API, evidenciando que mais de $60 \%$ estavam sendo financiados pelos próprios países da América do Sul, que demonstraram, pelo menos até 2016, um compromisso com a agenda e o avanço da integração física regional.

Outras fontes de financiamento com distintos graus de participação, variando de $13 \%$ a $0,3 \%$, dos maiores aos menores, foram: BID, CAF, financiamentos binacionais, Fundo para a Convergência Estrutural do Mercosul (Focem), Fonplata, BNDES, ${ }^{15}$ Uniāo Europeia, Japan Bank for International Cooperation (JBIC), governo chinês, além de bancos privados e outras formas de financiamento público e privado. ${ }^{16}$

$\mathrm{O}$ andamento da agenda integracionista a partir de 2011 explicita mudanças importantes sobre a questão do financiamento desde a IIRSA e, sobretudo, no Cosiplan. No documento de balanços da IIRSA, elaborado pelo BID em 2011, dez anos após sua criação, especialistas identificaram como o principal problema à implementação de projetos de integraçáo física sul-americana o financiamento, revelando, até então, uma baixa participação do setor privado nos investimentos logísticos. ${ }^{17}$

15. Sobre a atuação do BNDES em financiamento das carteiras IIRSA e Cosiplan, destaca-se que o banco, até 2017, participou apenas em dois projetos dessas agendas de integração, ambos associados à pavimentação de trechos rodoviários na Bolívia nas regiões sul e sudoeste do país (Wegner, 2018). Com o foco de financiamento, prioritariamente, a empresas brasileiras, Neves (2018, p. 323) observa que a participação do banco em projetos infraestruturais na América do Sul, a partir de 2000, relacionou-se a obras negociadas "a partir de relações bilaterais com os países sul-americanos, em uma relação direta com os governos vizinhos", e não pelos mecanismos IIRSA e Cosiplan. Ademais, a autora pontua a atuação do BNDES financiando a expansão e a internacionalização de empresas brasileiras, em especial grandes construtoras e companhias de engenharia.

16. Informações acerca da questão do financiamento tanto da carteira total do Cosiplan quanto da API constam no relatório de 2016, disponível em: <https://www.flipsnack.com/IIRSA/informe-de-la-cartera-de-proyectos-delcosiplan-2016.html>

17. Ver também Honório (2013). 
Caracterizando-se por setor da infraestrutura econômica, ressalta-se, todavia, que o setor privado, antes alinhado a um inicial e maior interesse em projetos associados às telecomunicaçóes durante o contexto das privatizaçóes, no âmbito do Cosiplan, voltar-se-ia, crescentemente, a alguns projetos de transporte e energia, vislumbrando concessóes e PPPs.

Isso configura um ponto de partida relevante quanto aos elementos que explicam uma maior execução dos projetos no âmbito do Cosiplan, já que nesta nova agenda foi gradativamente ampliando-se a participação de grandes empresas privadas de engenharia, especializadas na construção e na operacionalizaçáo de grandes obras no financiamento dos projetos, particularmente na API, da fase de estudos (junto ou mesmo substituindo Tesouros Nacionais e organizações financeiras como o BID e a CAF) a obras e operacionalizaçôes de fato, de vias e serviços. A princípio, esse movimento se deu via PPP, seguindo, a partir de 2015, por meio de concessóes a empresas privadas - nacionais, regionais e, progressivamente, estrangeiras, destacando a inserçâo chinesa nos últimos anos (2017-2019) em projetos voltados aos segmentos modais fluvial (no centro-norte do subcontinente) ${ }^{18}$ e ferroviário (na regiáo centro-sul) (Ray et al., 2016).

Nesse sentido, e seguindo na identificação dos principais aspectos e razóes à evolução da carteira de investimentos no Cosiplan, e quanto à própria integração física do subcontinente a partir da criação da IIRSA, a próxima subseção aprofunda a reflexão sobre os fatores que ajudam a compreender tal evolução, que, adversa e posteriormente, fundamentam o declínio do ímpeto físico-integracionista na América do Sul.

\subsection{Assimilando a compreensão entre a inflexão e a reversão da integração física sul-americana}

O resultado econômico positivo do período compreendido, principalmente, entre 2004 e 2011, com o produto interno bruto (PIB) médio de 4,25\%, ${ }^{19}$ nos ajuda a perceber que, quando da conformação do Cosiplan, a situação da América do Sul era razoavelmente animadora para os parâmetros regionais das últimas décadas do século passado.

Junta-se ao fator econômico, como uma segunda principal razão para o andamento dos projetos de integração física, além de aceleração na execução de fases (de pré-execução para perfil e daqui para execução e conclusão), um outro fator caracterizado por três tipos de avanços ocorrentes coetaneamente no subcontinente, sendo este o que aqui delimitamos como institucional-político-diplomático.

18. Particular e claramente quanto a mudanças na composição do financiamento dos projetos relativos ao Eixo Amazonas de integração, conforme analisado detalhadamente em Virga (2019).

19. Excetuando 2009, com uma queda no PIB de 1,8\%. Ambos a preços constantes de 2010. Disponível em: <https:// bit.ly/2PatqeZ>. Acesso em: 30 jul. 2020. 
Tal fator articula-se, a priori, a uma ampliação do diálogo e da cooperação entre os países da região, além da realização de encontros e reunióes entre seus governantes, resultando no adensamento de diversas atividades técnicas e na elaboração de documentos consensuados regionalmente, sobretudo entre 2008 e 2014. Relaciona-se, ademais, a uma crescente efetivação da Unasul, que, até então, parecia mostrar certo upgrade no tocante a organizações internacionais governamentais voltadas à integração regional. Segundo Herz, Tabak e Hoffmann (2015), são esses tipos de organização que asseguram a governança global e configuram um passo relevante ao processo de institucionalização das relaçôes internacionais.

Por esse ângulo, destaca-se o trabalho de Luigi (2017), o qual separa o desenvolvimento da Unasul em três fases: gênese, de 2008 a 2011, com forte atuação governamental; efetivação, de 2011 a 2014, como o auge de sua institucionalidade (por meio, inclusive, de diplomacia presidencial, como discute o autor) e relevante organização e ações executadas; ${ }^{20}$ e, por fim, estagnação, de 2014 a 2017, marcada por uma crescente desarticulação das instituiçóes e iniciativas criadas, com uma clara desaceleração na atuação da Unasul e de seus conselhos, sobretudo a partir de 2016, e certa desestabilizaçáo econômica e política, que culminaria num impeachment no Brasil.

Adicionalmente, Rodríguez (2009) ressalta a relevância do Cosiplan figurando no contexto recente da América do Sul como um marco em termos de organização e compromisso com a integração física, ao evidenciar, por exemplo, açôes mais articuladas quanto a delimitaçôes na estruturação de custos e distribuição de benefícios, coordenação de financiamento com base em organismos nacionais, regionais e internacionais e maior detalhamento de aspectos regulatórios relativos à infraestrutura.

Ademais, não poderíamos deixar de pontuar o papel de grandes empresas de engenharia e construçáo, com atuação regional e internacional, na operacionalização de obras e serviços vinculados à infraestrutura dos transportes na América do Sul durante a primeira década e meia dos anos 2000, cuja expressão alcançou o ápice com a conhecida e, posteriormente, muito criticada (nacional e regionalmente, devido aos efeitos políticos decorrentes da corrupçáo) empresa brasileira Odebrecht (entre outras) - operadora de projetos logísticos e de irrigação na região, ${ }^{21}$ por meio, até então, de sua subsidiária Odebretch Latin Investment.

20. Luigi $(2017$, p. 193) salienta que, durante o período mais efetivo da Unasul, "houve uma intensa atividade na organização, atestada pela produção documental, e uma forte institucionalização, com a complexificação da estrutura existente".

21. Concessionária, por exemplo, da rodovia IIRSA Norte (parte da agenda do Eixo Amazonas na API do Cosiplan) e proprietária, até novembro de 2016 (quando vende 100\% de suas ações), das empresas CTO e H2Olmos, operadoras do Projeto Olmos de irrigação de relevante área desértica peruana, hoje produtora de frutas, inclusive para exportação. 
Porém, o lançamento, ao final de 2014, da chamada Operação Lava Jato ajudaria a colocar "uma pá de cal" no projeto físico-integracionista sul-americano. ${ }^{22}$

Assim, da mesma forma que o crescimento econômico, associado a uma maior institucionalidade e coordenação política-governamental em âmbito regional, e a articulação com empresas de porte na construção de grandes projetos de infraestrutura explicam as principais razóes para o avanço dos projetos na agenda do Cosiplan, seria uma reviravolta nessas mesmas três esferas - econômica, política e empresarial privada - que afundaria a integração física em marcha no subcontinente, como discutiremos, com maior foco no aspecto político, na próxima seção.

\section{A INTEGRAÇÃO FÍSICA DA AMÉRICA DO SUL EM ESCANTEIO: REVERSÃO DE CENÁRIO E PERSPECTIVAS}

O período entre 2000 e 2020 representa um contexto de espectro econômico e político diverso e não "homogêneo" entre os doze países da América do Sul, no que concerne a ideias, rompantes e obras relacionadas ao tema da infraestrutura de transportes como agenda e pauta para uma maior integraçáo regional. Todavia, e como discutido anteriormente, de modo geral, planos e projetos infraestruturais e logísticos mostraram avanços alinhados a objetivos de integração física no âmbito subcontinental, sobretudo até 2015-2016.

Com relação ao aspecto econômico, a emergência da China como ator econômico global impactaria diretamente toda a América Latina e, portanto, do Sul, no tocante a um intrincado movimento de reinserção produtiva na Divisão Internacional do Trabalho (DIT), resultando em vultosos fluxos de exportação (sobretudo de produtos agrominerais) à potência asiática ${ }^{23}$ durante os chamados boom e pós-boom do preço das commodities. ${ }^{24}$

Já quanto ao aspecto da política, na transição entre governos de direcionamento liberal da década de 1990 para governos chamados progressistas nos anos 2000, assistiu-se a um novo ambiente político na América do Sul. Nele, logrou-se avançar, de modo mais direto e diretivo, um fortalecimento do diálogo regional visando ampliar relaçóes em vários campos, de sociais e econômicos e relativos à defesa e segurança entre os países ao próprio avanço da integração física regional - haja vista que o lançamento da própria IIRSA em 2000 foi realizado

22. Não configura intuito aqui debater sobre isso, mas para se ter uma ideia sobre o impacto da referida operação na paralisação ou mesmo na suspensão de diversos projetos infraestruturais na América do Sul, muitos desses associados à agenda do Cosiplan, ver a matéria de Carvalho (2016).

23. Medeiros e Cintra (2015) atentam ao fato de que, até 2000, a China não ocupava lugar de destaque como destino das exportações latino-americanas. Foi em razão de sua consolidação como centro manufatureiro mundial que impactos mais diretos foram observados, a partir do que caracterizam como efeitos de demanda e estrutura, sobre os vários países da região.

24. Sobre isso, consultar, de reflexão mais "otimista" à crítica, Cepal (2015) e Svampa e Slipak (2015). 
pelos então presidentes FHC, no Brasil, e Alberto Fujimori, no Peru, conhecidos por posiçôes (políticas e geopolíticas) bastante alinhadas com os países do norte, leia-se Estados Unidos.

Então, na onda progressista a partir de 1999 e até aproximadamente 2014, destacou-se a atuação de alguns dos principais entusiastas de uma maior integração do subcontinente, os então presidentes Hugo Chavez (1999-2013), Lula (2003-2010), Evo Morales (2006-2019) e Rafael Corrêa (2007-2017), resultando na criação da Unasul e do Cosiplan. Acrescenta-se aqui que, durante todo esse período e, em especial, entre esses países (Venezuela, Brasil, Bolívia e Equador), foram ampliadas fortemente as relações comerciais, diplomáticas e políticas também com outros países do sul, por meio do Brics (acrônimo para Brasil, Rússia, Índia, China e África do Sul).

Assim, não relevando modificações no cenário, a deposição da presidenta do Brasil Dilma Rousseff e o fato de que o Cosiplan apresentou uma maior execução de obras e entregas entre 2013 e 2016, ainda que com a crescente participação do setor privado na evolução de projetos e após reversóes iniciais no âmbito macroeconômico, ressaltamos que projetos de integração física se converteram em realidades até entâo.

Todavia, a situação econômica e política regrediu bem a partir da segunda metade da atual década. Primeiro, quanto à economia regional e internacional, as fases anteriores de crescimento quase ininterruptos transmutar-se-iam em recorrentes crises com resultados negativos - sobretudo macroeconômicos, ${ }^{25}$ fiscais e de capacidade de inversão pelo lado do setor público. ${ }^{26} \mathrm{E}$ tudo isso associado a um complexificado contexto político interno na América do Sul.

O período progressista passaria a um contexto mais liberal - conservador, como discute Santos (2018). E também mais instável. A partir da deposição do entâo presidente Fernando Lugo no Paraguai em 2012, assistimos, seguidamente, ao seguinte: $i$ ) entre 2013 e 2015, respectivamente, instabilidades político-institucionais no Brasil e na Venezuela (com esse segundo país, posteriormente, sofrendo também sançóes internacionais); ii) em 2016, a conclusão no processo de impeachment da então presidenta do Brasil Dilma Rousseff; iii) em 2017, com a eleição do presidente Lenin Moreno no Equador, o país assume uma posição diametralmente oposta ao seu antecessor; e iv) em 2019, a reeleiçâo do presidente Evo Morales leva a Bolívia a uma instabilidade política

25. Com o PIB médio regional entre 2015 e 2019 de -0,72\%. Disponível em: <https://bit.ly/2PatqeZ>. Acesso em: 30 jul. 2020.

26. Como principais reversões na esfera socioeconômica na América Latina, Cervo (2016) ressalta a retração do comércio exterior, dos investimentos e do próprio crescimento, impactando a redução produtiva industrial, de consumo e renda salarial (fruto de rápida ampliação do desemprego). 
que culmina em um golpe cívico-militar. Evidenciava-se, assim, um processo de forte reversão da conjuntura política regional.

Alia-se à maior instabilidade um recrudescimento do conservadorismo na esfera política regional por meio da chegada ao poder de presidentes como Lenin Moreno no Equador, Maurício Macri na Argentina, Sebastián Piñera no Chile e, com maior expressão, Jair Bolsonaro no Brasil. A integração da infraestrutura de transportes sul-americana, antes em curso, é radicalmente revertida, com a priorização de um alinhamento político subordinado, especialmente aos Estados Unidos, escanteando a integração física e o próprio processo de integração regional.

Como resultado dessa mudança regional, a Unasul seria formalmente esvaziada com a saída do Brasil em abril de 2019, consequentemente encerrando as atividades do Cosiplan. Assim, a reversão econômica e política dos últimos anos parece "enterrar" de vez, tanto as iniciativas que, como a IIRSA e o Cosiplan, lograram em avançar na ampliação da infraestrutura de transportes sul-americana quanto o diálogo político coordenado e diretivo correspondente e tão necessário a uma maior integração, como um primeiro passo base ao desenvolvimento sul-americano.

\section{CONSIDERAÇÕES FINAIS}

Partindo do diagnóstico da situação infraestrutural da América do Sul no período 2000-2020, a partir da identificaçấo dos principais gargalos técnico-setoriais a relevantes impasses e problemas de cunho econômico, político e socioespacial, com base nos diferentes modais de transporte, evidenciou-se uma oferta de infraestrutura física no subcontinente bastante debilitada e fortemente concentrada nos principais centros produtivos e faixas litorâneas, em especial no Cone Sul, em ambas as costas. Uma região historicamente estruturada a se conectar "para fora".

A partir dos anos 2000, foram logrados avanços com o lançamento de agendas comuns de integraçáo física regional por meio da IIRSA e, principalmente, do Cosiplan, no âmbito da Unasul. Além disso, observaram-se progressos desde a organização de uma agenda comum de investimentos em transportes e logísticos necessários em todos os seus doze países até uma maior integração física e a estruturação de EIDs - pela primeira vez, de forma consensuada pelos doze.

Somam-se a isso os decorrentes avanços em termos de execução de diversos projetos, com obras concluídas no período 2000-2020, notadamente após a criação da API do Cosiplan. Tal API, revisada após a incorporação da AIC no âmbito da IIRSA, pormenorizou os estudos, ampliando a articulação da infraestrutura física para outros segmentos sociais e econômicos, assim como perspectivas de impactos, o que resultou em efeitos importantes quanto aos primazes objetivos da 
infraestrutura de transportes associados à oferta - isto é, visando a priori conectar espaços e países, as iniciativas recentes apresentaram avanços consideráveis.

Diante do exposto, procurou-se evidenciar certo esforço e impulsionamento no tocante a uma maior cooperação e coordenação entre os países da região no planejamento e, sobretudo, na exequibilidade de uma agenda de integraçáo física e territorial no subcontinente. O objetivo é impulsionar tal perspectiva junto a uma visão estratégica da América do Sul, com os Estados nacionais desempenhando, com certa eficácia, um papel diretivo, ou ao menos norteador, de projetos e iniciativas em esfera regional, viabilizando, inclusive, a conclusão de diversas obras, em especial durante o contexto do Cosiplan no âmbito da Unasul.

Nesse sentido, reconhecemos que tal conselho representou mais um ponto de inflexão do que mera continuação, no que concerne a uma histórica-estrutural situação de uma América do Sul mais integrada com outros continentes que com ela mesma e à própria iniciativa da IIRSA, em seus objetivos principais e alcances, ampliando focos de atuação e impactos decorrentes da infraestrutura de transportes, de forma tangente e articulada a outros conselhos da Unasul. ${ }^{27}$ Assim, reiteramos a maior importância do Cosiplan na trajetória recente de iniciativas para a integração física sul-americana, ainda que permaneçam insuficiências e entraves. ${ }^{28}$

A queda de governos progressistas, contudo, resultou no fim efetivo da Unasul e do Cosiplan. Tal reversão ganha complexidade, afastando quaisquer prospectivas de avanço da integração física em âmbito subcontinental pautada por objetivos mais amplos de uma integração regional da América do Sul. Com um cenário político e econômico cada vez mais instável e nebuloso na América do Sul, o futuro, ainda que apontando para enormes incertezas em termos prospectivos, evidencia que o tema infraestrutura física e cooperação política no subcontinente parece, literalmente, ter sido desintegrado.

\section{REFERÊNCIAS}

\section{ACI - AIRPORTS COUNCIL INTERNATIONAL. World airport traffic} report. [s.l.]: [s.n.]: 2015.

ARAUJO, J. T. Da IIRSA ao Cosiplan: desafios da integração física da América do Sul. [s.l.]: [s.n.], 2012.

27. Como os de Economia e Finanças, Defesa e Saúde, ambos com estreitas ligações com a infraestrutura física. 28. Por exemplo, melhorias necessárias do planejamento de planos e obras, maior consulta e participação da sociedade, apresentação relatórios pormenorizados de impacto ambiental e maior comprometimento estatal no combate à corrupção, recorrentemente evidenciada na análise de diversos tipos de projetos infraestruturais, sobretudo em grandes obras. 
ARVIS, J.-F. et al. Connecting to compete 2018: trade logistics in the global economy - the logistics performance index and its indicators. Washington: The World Bank, 2018.

BATISTA, E. da S. Infrastructure for sustainable development and integration of South America. Rio de Janeiro: Expressão e Cultura, 1996.

BECKER, B. K. Os eixos de integração e desenvolvimento e a Amazônia. Revista Território, ano IV, n. 6, jan./jun. 1999.

CARRION, M. da C.; PAIM, E. S. IIRSA: desvendando interesses. Porto Alegre: Amigos da Terra, fev. 2006.

CARVALHO, C. Lava-Jato já suspendeu 16 projetos em seis países. O Globo, 11 dez. 2016. Disponível em: <https://glo.bo/2Xh793y>. Acesso em: 31 jul. 2020.

CECENAA, A. E.; AGUILAR, P.; MOTTO, C. Territorialidad de la dominación: Integración de la Infraestructura Regional Sudamericana (IIRSA). Buenos Aires: Observatório Latinoamericano de Geopolítica, 2007.

CEPAL - COMISIÓN ECONÓMICA PARA AMÉRICA LATINA Y EL CARIBE. América Latina y el Caribe y China: hacia una nueva era de cooperación económica. Santiago: Cepal, mayo 2015.

CERVO, A. A marcha lenta da América Latina no século XXI. Austral: Revista Brasileira de Estratégia e Relaçôes Internacionais, v. 5, n. 9, p. 11-32, jan./jun. 2016.

COSIPLAN - CONSELHO SUL-AMERICANO DE INFRAESTRUTURA E PLANEJAMENTO. Cartera de proyectos 2016. [s.l.]: Cosiplan, 2016. Disponível em: <http://bit.ly/2IxK18H>. Acesso em: 22 set. 2017.

COSTA. D. Integrar é desenvolver a América do Sul. In: FUNAG - FUNDAÇÃO ALEXANDRE DE GUSMÃO. Integraçáo da América do Sul. Brasília: Funag, 2010. p. 47-70.

América do Sul: integração e infraestrutura. Rio de Janeiro: Capax Dei, 2011.

FIGUEIREDO, A. G. de B. Simón Bolívar: uma persistência latino-americanapensamento político e integração. 2015. Tese (Doutorado) - Programa de Pós-Graduação em Integração da América Latina, Universidade de São Paulo, São Paulo, 2015.

GALLO, P. V. El axioma del transporte. Revista Perspectiva, Colômbia, n. 17, 2008. GALVÃO, A. C. F.; BRANDÃO, C. A. Fundamentos, motivaçôes e limitaçôes da proposta dos Eixos Nacionais de Integração e Desenvolvimento. In: GONÇALVES, M. F.; BRANDÂO, C. A.; GALVÃO, A. C. F. (Org.). Regióes e cidades, cidades nas regióes: o desafio urbano-regional. São Paulo: Editora Unesp, 2003. p. 187-206. 
HANDABAKA, A. R. Corredores interoceánicos suramericanos: criterios logísticos de selección. Lima: Fimart S.A.C. Editores, 2006.

HERZ, M.; TABAK, J.; HOFFMANN, A. R. Organizaçóes internacionais: história e práticas. 2. ed. Rio de Janeiro: Elsevier, 2015.

HONÓRIO, K. dos S. O significado da iniciativa para a Integraçáo da Infraestrutura Regional Sul-Americana (IIRSA) no regionalismo sul-americano (2000-2012): um estudo sobre a iniciativa e a participação do Brasil. 2013. Dissertação (Mestrado) - Pontifícia Universidade Católica de São Paulo, São Paulo, 2013.

JANUÁRIO, M. H. Procedimento para determinaçáo de índices de acessibilidade de transporte e tratamento cartográfico dos mesmos. 1995. Dissertação (Mestrado) - Instituto Militar de Engenharia, Rio de Janeiro, 1995.

LUIGI, R. A integraçáo regional na América do Sul: a efetividade da União das Naçôes Sul-Americanas (Unasul). 2017. Tese (Doutorado) - Universidade Estadual de Campinas, Campinas, 2017.

MARIANO, M. P. O papel do Brasil na integração da infraestrutura da América do Sul: limites institucionais e possibilidades de mudanças. In: DESIDERÁ NETO, W. A. (Org.). O Brasil e novas dimensóes da integraçáo regional. Rio de Janeiro: Ipea, 2014. p. 229-290.

MEDEIROS, C. A.; CINTRA, M. R. V. P. Impacto da ascensão chinesa sobre os países latino-americanos. Brazilian Journal of Political Economy, v. 35, n. 1, p. 28-42, 2015.

MOREIRA, J. B. de B. A nova geopolítica mundial e seus reflexos para o Brasil. Revista da Escola Superior de Guerra, v. 23, n. 48, p. 7-22, 2007.

NAZARÉ, R. F. Globalizaçáo, o transporte e a Amazônia brasileira. Belém: Editora Cejup, 2001.

NEVES, B. C. Política externa brasileira, BNDES e a integração da infraestrutura sul-americana: uma análise da IIRSA/Cosiplan (2000-2017). Monçóes: Revista de Relaçôes Internacionais da UFGD, v. 7, n. 14, p. 312-351, 2018.

PADULA, R. Infraestrutura, geopolítica e desenvolvimento na integraçáo sul-americana - uma visão crítica à IIRSA. Rio de Janeiro: Leal, 2011.

. Do IIRSA ao Cosiplan da Unasul: a integraçấo de infraestrutura na América do Sul nos anos 2000 e suas perspectivas de mudança. In: DESIDERÁ NETO, W. A. (Org.). O Brasil e novas dimensóes da integraçáo regional. Rio de Janeiro: Ipea, 2014. p. 291-352. 
PARES, A. Uma América do Sul integrada e próspera: uma meta em andamento. Salvador: Seplan, 2006.

PAZ, A. da. Em busca da integração interna: diagnóstico da matriz de transporte de integração sul-americana. In: COSTA, D. América do Sul: integração e infraestrutura. Rio de Janeiro: Capax Dei, 2011. p. 29-98.

QUINTANAR, S.; LÓPEZ, R. O plano de ação para a Integração da Infraestrutura Regional Sul-Americana (IIRSA): oportunidades e riscos - seu significado para o Brasil e a Argentina. Revista Brasileira de Política Internacional, v. 46, n. 1, p. 213-221, 2003.

RAY, R. et al. (Ed.). China en América Latina: lecciones para la cooperación Sur-Sur y el desarrollo sostenible. Lima: Universidad del Pacífico; Boston University, 2016. p. 43-88. Disponível em: <https://bit.ly/2Xc3YtQ>. Acesso em: 29 jul. 2020.

RODRÍGUEZ, E. G. Infraestructura e integración en América Latina. Boletín Económico de ICE, n. 2974, 2009.

SANTOS, F. L. B. dos. Uma história da onda progressista sul-americana (1998-2016). São Paulo: Editora Elefante, 2018.

SELA - SISTEMA ECONÓMICO LATINOAMERICANO Y DEL CARIBE. Infraestructura física para la integración en America Latina y el Caribe. Caracas: Sela, jun. 2011.

SVAMPA, M.; SLIPAK, A. M. China en América Latina: del Consenso de los Commodities al Consenso de Beijing. Revista Ensambles, año 2, n. 3, p. 34-63, 2015. THÉRY, H.; MELLO, N. A. de. Atlas do Brasil: disparidades e dinâmicas do território. 2. ed. São Paulo: Edusp, 2009.

VICKERMAN, R.W. Accessibility, attraction, and potential: a review of some concepts and their use in determining mobility. Environment Planning A, v. 6, n. 6, p. 675-691, 1974.

VIRGA, T. Integraçáo física e desenvolvimento na América do Sul: transformações e prospectivas da infraestrutura de transportes na regiâo do "Eixo Amazonas" na Amazônia centro-ocidental (2000-2018). 2019. Tese (Doutorado) - Universidade Estadual de Campinas, Campinas, 2019.

VITTE, C. de C. S. Planejamento territorial e os impactos socioeconômicos da IIRSA no território brasileiro: atores, conflitos e interesses. In: ENCUENTRO DE GEÓGRAFOS DE AMÉRICA LATINA, 12., 2009, Montevidéu. Anais... Montevidéu: [s.n.], 2009. v. 1. p. 1-17. 
WEGNER, R. C. Integração e desenvolvimento econômico: estratégias de financiamento do investimento de infraestrutura sul-americana. Economia e Sociedade, v. 27, n. 3, Campinas, set./dez. 2018.

WILMSMEIER, G. Geografía del transporte de carga: evolución y desafíos en un contexto global cambiante. Santiago: Cepal, 2015. (Serie Recursos Naturales e Infraestructura, n. 175).

\section{BIBLIOGRAFIA COMPLEMENTAR}

COSIPLAN - CONSEJO SURAMERICANO DE INFRAESTRUCTURA Y PLANEAMIENTO. Composición sectorial, sub-sectorial y tipo de obra de los proyectos de la cartera del Cosiplan 2016. [s.l.]: Cosiplan, 2016. Disponível em: <http://bit.ly/2R1oSrr>. Acesso em: 12 fev. 2017.

INTAL - INSTITUTO PARA LA INTEGRACIÓN DE AMÉRICA LATINA Y EL CARIBE. IIRSA diez años después: sus logros y desafíos. 1. ed. Buenos Aires: Intal, 2011. 